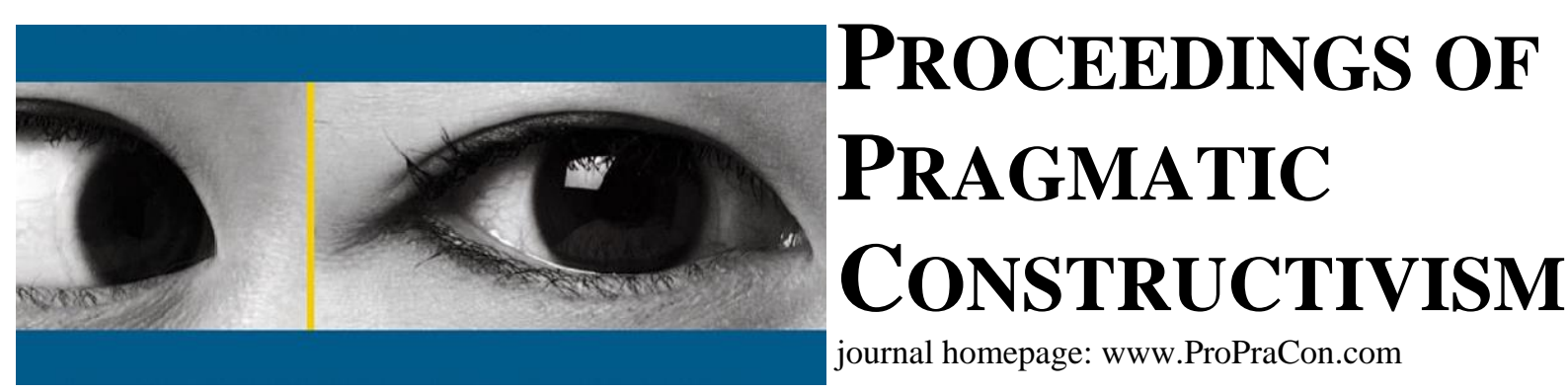

\title{
Editorial: constructing a journal
}

\author{
Rainer Lueg \\ Associate Professor of Management Accounting and Control \\ Aarhus University; School of Business and Social Sciences; Department of Economics and Business \\ Fuglesangs Allé 4, 8210 Aarhus V, Denmark; rlueg@asb.dk
}

\section{The scope of ProPraCon}

"Proceedings of Pragmatic Constructivism" (ProPraCon) is a double-blind peer-reviewed journal that publishes original research related to a pragmatic approach to constructivism. Pragmatic constructivism is a theoretical perspective in which actors in contemporary organizations to construct and understand their realities while accounting for different given facts in the mid-term, such as the institutional or brute environmental facts that define their realm of action. The journal is open to many fields of research, such as accounting, business, humanities, social sciences, and technology. In particular, this journal has a specific interest in the way actors use (non-)financial information and management policies to create realities in any type of organization.

The fundamental reason to establish this journal was the specific need to create an outlet for research that relates to the newly founded theory of Actor-Reality-Construction (Jakobsen, Johanson, \& Nørreklit, 2011; Nørreklit, Nørreklit, \& Mitchell, 2007, 2010; Nørreklit, Nørreklit, \& Israelsen, 2006; Seal, 2012). The first article in this issue, written by Hanne Nørreklit, elaborates on the aims and scope of the Research Group on Actor-Reality Construction, and thereby directly on the scope of this journal.

I especially thank Gudrun Baldvinsdottir and Trond Bjørnenak, whose ideas lay the foundation of this journal. I look forward to my 5 year term as Editor-in-Chief of this journal until 2015, together with the publisher Hanne Nørreklit and the Associate Editors Gudrun Baldvinsdottir (Trondheim Business School), Annick Ancelin-Bourguignon (ESSEC Business School), Falconer Mitchell (Edinburgh University), Lennart Nørreklit (Aalborg University), and Will Seal (Loughborough University).

\section{The structure of ProPraCon}

Besides the Editorial, ProPraCon has five sections to which authors may submit their work. The section 'Essays' contains full papers. The section 'Speeches' enables authors to publish an improved version of their work that they presented at the refereed conferences and workshops of the Research Group for Actor-Reality Construction (ARC). The section 'Notes' allows these authors to publish their peer-reviewed work in the form of a structured or extended abstract. 'Contemplations' contain shorter pieces, such as reviews of books. 'Dialogs' is the last section; it contains the edited transcripts of roundtable discussions of the aforementioned conferences.

\section{Double-blind peer-review process}

All published work in ProPraCon is double-blind peer-reviewed. Authors have the option to submit their work to the editors for a review. As an alternative, authors may also submit their work to the review process of the ARC conferences (and workshops). After (again) revising their work according to the discussions of the conference, they are allowed to publish this peer-reviewed version in ProPraCon.

\section{Copyrights}

ProPraCon assumes a very liberal copyright policy. The journal assumes the non-exclusive rights to publish and store the work of its authors, once they have consented to a publication. Since the rights to publish are non-exclusive, authors are free to re-use their work, e.g., to publish it in other media (as ProPraCon aims at publishing proceedings). Hence, it 
is explicitly allowed that works submitted to ProPraCon may be published in a somehow similar form in other media. Yet, submitting authors warrant that the work is not an infringement of any existing copyright and will indemnify the publisher against any breach of such warranty.

This new structure of a scientific journal as well as the real-time peer-review process appear to be more contemporary and hopefully foster a faster and more interactive exchange of recent research.

\section{References}

Jakobsen, M., Johanson, I.-L., \& Nørreklit, H. (Eds.). 2011. An Actor's Approach to Management: Conceptual Framework and Company Practices. Copenhagen: DJØF.

Nørreklit, H., Nørreklit, L., \& Mitchell, F. 2007. Theoretical Conditions for Validity in Accounting Performance Measurement. In A. Neely (Ed.), Business Performance Measurement. Cambridge: Cambridge University Press.

Nørreklit, H., Nørreklit, L., \& Mitchell, F. 2010. Towards a paradigmatic foundation for accounting practice. Accounting, Auditing \& Accountability Journal, 23(6): 733-758.

Nørreklit, L., Nørreklit, H., \& Israelsen, P. 2006. The validity of management control topoi: towards constructivist pragmatism. Management Accounting Research, 17(1): 42-71.

Seal, W. 2012. Some proposals for impactful management control research. Qualitative Research in Accounting \& Management, 9(3): 228-244. 